\title{
Genetic Polymorphism at Codon 463 in the katG Gene in Isoniazid-Sensitive and -Resistant Isolates of Mycobacterium tuberculosis from the Middle East
}

\author{
S. Ahmada E. Mokaddas ${ }^{a}$ A.T. Abal ${ }^{b}$ G.F. Araj ${ }^{c}$ E. Fares ${ }^{d}$ A.S. Mustafa ${ }^{a}$ \\ Departments of a Microbiology and b ${ }^{\mathrm{D}}$ Medicine, Faculty of Medicine, Kuwait University, Kuwait; \\ 'Department of Pathology and Laboratory Medicine, American University of Beirut, Lebanon; \\ dDepartment of Health and Laboratory Services, Rashid Hospital, Dubai, UAE
}

\section{Key Words}

Mycobacterium tuberculosis · Isoniazid · KatG gene •

R463L mutation - Drug resistance

\begin{abstract}
Objective: To determine whether substitution R463L within the katG gene is associated with resistance to isoniazid in clinical isolates of Mycobacterium tuberculosis recovered from tuberculosis (TB) patients from the Middle East. Methods: A total of 113 clinical isolates of M. tuberculosis obtained from TB patients residing in Kuwait, UAE and Lebanon were used. The isolates were characterized as isoniazid-susceptible $(n=25)$ or -resistant ( $n=88$ ) based on drug susceptibility testing by BACTEC 460 TB system. The presence of R463L mutation within the kat $G$ gene of each isolate was detected by amplification of the DNA region around codon 463 by polymerase chain reaction (PCR) followed by digestion with restriction endonuclease Ncil to generate PCRrestriction fragment length polymorphism. The results with selected isolates were further confirmed by DNA sequencing. Results: The mutation R463L was detected in 46 of 59 isoniazid-resistant clinical $M$. tuberculosis isolates from Kuwait, 9 of 12 from UAE and 3 of 17 from Lebanon. The prevalence of this substitution was much
\end{abstract}

\section{KARGER}

Fax +41613061234

E-Mail karger@karger.ch

www. karger.com

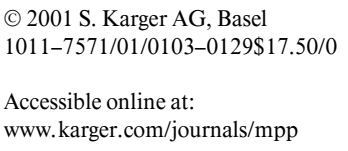

higher in isolates recovered from patients of South Asian/Southeast Asian origin (41/49, 84\%) than from patients of Middle Eastern origin (17/39, 44\%). Although all the 7 isoniazid-susceptible isolates of $M$. tuberculosis from Lebanon (recovered exclusively from Middle Eastern patients) contained arginine at codon 463, 3/7 and 10/11 isoniazid-susceptible strains from Kuwait, recovered from Middle Eastern and South Asian patients, respectively, contained leucine at codon 463. Conclusion: The results show that genetic polymorphism exists at codon 463 in the katG gene of $M$. tuberculosis recovered from patients of different ethnic backgrounds. The data also show that substitution R463L within the katG gene does not contribute to isoniazid resistance.

Copyright $\odot 2001$ S. Karger AG, Basel

\section{Introduction}

Human tuberculosis (TB) caused by virulent Mycobacterium tuberculosis is responsible for $26 \%$ of all avoidable adult deaths worldwide. It is estimated that 8 million individuals develop active disease and 2 million people die of TB each year [1]. During the last decade, the incidence of TB has increased even in developed countries, particularly involving immigrant populations and human immu- 
nodeficiency virus-infected individuals [2]. Moreover, the resistance of $M$. tuberculosis to the frontline anti-TB drugs has been steadily increasing and several outbreaks caused by multidrug-resistant strains of $M$. tuberculosis have been reported from nearly all parts of the globe [3]. Major factors in the control of TB are rapid detection, drug susceptibility testing of all isolates of $M$. tuberculosis, adequate therapy and restricting close contacts to arrest further transmission $[1,3]$. The phenotypic drug susceptibility testing by BACTEC requires between 4 and 14 days after the primary culture has been isolated [4]. Thus, there is a great need for fast and reliable methods for drug susceptibility testing of $M$. tuberculosis to key anti-TB drugs.

Isoniazid and rifampin are the two most effective antiTB drugs and resistance of $M$. tuberculosis to these drugs is most likely to influence the outcome of therapy [5]. Though isoniazid is most efficient in killing the TB bacilli, resistance to this drug also develops most readily. The resistance to isoniazid is caused by a variety of mutations in at least three different genes of $M$. tuberculosis, i.e. $k a t G$ encoding catalase-peroxidase, inhA encoding enoyl acyl carrier protein (ACP) reductase and kasA encoding $\beta$-ketoacyl ACP synthase [6]. Clinically relevant high level resistance is mainly due to missense/nonsense mutations or small insertions/deletions within the $k a t G$ gene [7-10]. The $k a t G$ gene was initially sequenced from $M$. tuberculosis $\mathrm{H} 37 \mathrm{Rv}$ and contained serine at codon 315 (S315) and arginine at codon 463 (R463) [11]. In earlier studies, the isoniazid-susceptible clinical $M$. tuberculosis isolates from Europe and North America were also found to contain S315 and R463 while the majority of isoniazid-resistant strains contained serine-to-threonine substitution at codon 315 (S315T) and/or arginine-to-leucine substitution at codon 463 (R463L) [7-10]. The role of mutations at codon 315 is firmly established. Clinical isolates of $M$. tuberculosis with $\mathrm{S} 315 \mathrm{~T}$ substitution exhibit a high level of resistance to isoniazid and the same results were obtained when the mutation was introduced in wild-type M. tuberculosis by site-directed mutagenesis [12-14]. However, the role of the most common genetic alteration within the $k a t G$ gene, $\mathrm{R} 463 \mathrm{~L}$, in isoniazid resistance is not clear $[8,10]$. Some studies suggested that R463L causes low level resistance to isoniazid (MIC $<1 \mu \mathrm{g} / \mathrm{ml}$ ) while other studies involving a greater number of clinical isolates have shown that the same substitution is also present in fully susceptible clinical isolates [6, 7, 12]. Introduction of this mutation in wild-type $M$. tuberculosis by in vitro mutagenesis did not significantly affect the sensitivity to isoniazid [14]. Characterization of clinical isolates of $M$. tuberculosis from Singapore and China showed that the majority of isoniazid-susceptible strains contained R463L substitution suggesting that this mutation does not contribute to the resistance of $M$. tuberculosis to isoniazid [15].

This study was carried out to determine the prevalence of $\mathrm{R} 463 \mathrm{~L}$ substitution within the $\mathrm{kat} G$ gene in clinical isolates of $M$. tuberculosis from Middle Eastern countries. Our results confirm that polymorphism exists at codon 463 in the $\mathrm{kat} G$ gene in isoniazid-susceptible clinical $M$. tuberculosis isolates recovered from patients of different ethnic groupings.

\section{Materials and Methods}

Isoniazid-Resistant and-Susceptible M. tuberculosis Isolates

Isolates of $M$. tuberculosis from clinical specimens, their identification and drug susceptibility testing were performed using the BACTEC 460 TB system as reported earlier [16]. The isolates were considered resistant when bacterial growth occurred at a concentration of $1 \mu \mathrm{g}$ isoniazid $/ \mathrm{ml}$. A total of 88 isoniazid-resistant strains of $M$. tuberculosis isolated from TB patients were obtained from the Chest Diseases Hospital, Kuwait $(\mathrm{n}=59)$, Rashid Hospital, Dubai, UAE $(\mathrm{n}=12)$ and American University of Beirut Hospital, Beirut, Lebanon $(\mathrm{n}=17)$, respectively. In addition, a total of 25 (18 from Kuwait and 7 from Lebanon) isoniazid-susceptible clinical isolates of $M$. tuberculosis recovered from TB patients were also included in the study.

\section{Detection of R463L Mutation within the katG Gene}

The substitution of arginine with leucine at codon 463 (R463L) within the $k a t G$ gene of $M$. tuberculosis is accompanied by the loss of a restriction site for restriction endonuclease $N c i \mathrm{I}[8,11]$. Thus, the presence of $\mathrm{R} 463 \mathrm{~L}$ substitution within the $\mathrm{kat} G$ gene was determined by amplification of the $k a t G$ gene DNA region around codon 463 by polymerase chain reaction (PCR) followed by restriction endonuclease digestion of the PCR-amplified fragment with $N c i$ to generate restriction fragment length polymorphism (RFLP) as described by Cockerill et al. [8]. In brief, genomic DNA was prepared from the standard M. tuberculosis H37Rv as described previously and used as a control for amplification of $k a t G$ gene region around codon 463 by PCR [17]. The isoniazid-susceptible and -resistant clinical isolates of M. tuberculosis were obtained as heat-killed BACTEC liquid cultures. The genomic DNA from these cultures was obtained as follows. One milliliter of these cultures was heated at $95^{\circ} \mathrm{C}$ for $60 \mathrm{~min}$ followed by centrifugation at $12,000 \mathrm{~g}$ for $15 \mathrm{~min}$ and the supernatants obtained were used as the source of genomic DNA [18, 19]. A primer pair was synthesized for the amplification of the $k a t G$ gene region around codon 463 from the genomic DNA of $M$. tuberculosis isolates [11]. The sequences of the forward and reverse primers that should generate a 360-bp product in PCR were as follows:

\section{KatG1F: 5'-CCCGAGGAATTGGCCGACGAGTTC}

\section{KatG1R: 5'-GGTGCGAATGACCTTGCGCAGATC}

The reaction mixtures in a final volume of $50 \mu$ l contained Perkin-Elmer PCR buffer, 10 pmol of forward $(\mathrm{F})$ and reverse $(\mathrm{R})$ primers, $5 \mu \mathrm{l}$ of template DNA, $0.1 \mathrm{~m} M \mathrm{dNTP}$ and 2 units of AmpliTaq 
DNA polymerase. The cycling parameters included an initial denaturation at $95^{\circ} \mathrm{C}$ for $5 \mathrm{~min}, 2$ cycles of $1 \mathrm{~min}$ at $95^{\circ} \mathrm{C}, 30 \mathrm{~s}$ at $62^{\circ} \mathrm{C}$, $1 \mathrm{~min}$ at $72^{\circ} \mathrm{C}, 2$ cycles of $1 \mathrm{~min}$ at $95^{\circ} \mathrm{C}, 30 \mathrm{~s}$ at $60^{\circ} \mathrm{C}, 1 \mathrm{~min}$ at $72^{\circ} \mathrm{C}, 2$ cycles of $1 \mathrm{~min}$ at $95^{\circ} \mathrm{C}, 30 \mathrm{~s}$ at $58^{\circ} \mathrm{C}, 1 \mathrm{~min}$ at $72^{\circ} \mathrm{C}, 26$ cycles of $1 \mathrm{~min}$ at $95^{\circ} \mathrm{C}, 30 \mathrm{~s}$ at $56^{\circ} \mathrm{C}, 1 \mathrm{~min}$ at $72^{\circ} \mathrm{C}$ followed by an additional cycle of $10 \mathrm{~min}$ at $72^{\circ} \mathrm{C}$. The reactions were started by the addition of dNTPs (hot start) [20].

A portion of the amplified product was run on $2 \%$ agarose gel to confirm the amplification of the expected product. The rest of the PCR-amplified fragment was separated from unincorporated oligonucleotides and dNTPs by using Qiagen PCR purification columns, digested with restriction endonuclease $\mathrm{NciI}$ and the digested products were separated on $2.5 \%$ Nusieve Agarose gels run in Trisborate-EDTA (TBE) buffer to generate RFLPs. The amplified fragment from $M$. tuberculosis isolates containing arginine at codon 463 (R463) yields two fragments of 187 and $173 \mathrm{bp}$ while the fragment from isolates carrying the substitution $\mathrm{R} 463 \mathrm{~L}$ is not digested by $N c i \mathrm{I}$ and thus yields the original undigested fragment of $360 \mathrm{bp}[8,11]$.

\section{Sequencing of PCR-Amplified Products}

The PCR-amplified $k a t G$ gene fragment containing the region around codon 463 was subjected to direct DNA sequencing to confirm the results obtained with PCR-RFLP analysis. The PCR products were run on agarose gels in a TBE buffer and the DNA band corresponding to the amplified DNA was cut out, the DNA eluted and used as a template in sequencing reactions using the cycle DNA sequencing kit (Applied Biosystems Inc.). The reaction mixtures in a final volume of $20 \mu \mathrm{l}$ contained eluted DNA, 5 pmol of primer KatG1F and $9.5 \mu$ of the premix reaction components supplied in the kit. The cycling parameters for the sequencing reactions included an initial denaturation at $95^{\circ} \mathrm{C}$ for $5 \mathrm{~min}$ followed by 45 cycles of $1 \mathrm{~min}$ at $95^{\circ} \mathrm{C}, 30 \mathrm{~s}$ at $45^{\circ} \mathrm{C}, 1 \mathrm{~min}$ at $72^{\circ} \mathrm{C}$. The reaction products were extracted with phenol:chloroform, precipitated with ethanol, and the pelleted DNA was loaded on the sequencing gel exactly as described in the instructions supplied with the sequencing kit and standard molecular biology techniques [21].

\section{Results}

The most common genetic alteration found in isoniazid-resistant clinical isolates of $M$. tuberculosis involves an arginine-to-leucine substitution at codon 463 (R463L) in the $k a t G$ gene. The presence of this mutation at codon 463 results in the loss of recognition site for restriction endonuclease $\mathrm{Nci}$ (CCGGG to CCTGG) [8, 11]. The mutation results in different restriction patterns of PCRamplified fragments encompassing codon 463 with arginine or leucine at this position. In order to determine the prevalence of this substitution in isoniazid-susceptible and -resistant clinical isolates of $M$. tuberculosis from Middle Eastern countries, PCR-RFLP analyses were performed on a total of 25 isoniazid-susceptible and 88 isoniazid-resistant strains.

The PCR performed on 7 isoniazid-susceptible isolates from Beirut, Lebanon resulted in specific amplification of a 360-bp DNA fragment (the data from 4 isolates are shown in fig. 1a, lanes 1-4) that gave two fragments of 187 and $173 \mathrm{bp}$ when digested with the restriction enzyme $N c i$ (the restriction pattern for the same 4 isolates is shown in fig. 1b, lanes 1-4). This implied that the katG gene in these isolates contains arginine at codon 463 (R463). The results were confirmed by direct DNA sequencing of the amplified product from one isolate (data not shown). When PCR was performed on 18 isoniazidsusceptible clinical isolates of $M$. tuberculosis from $\mathrm{Ku}-$ wait, again a specific DNA product of $360 \mathrm{bp}$ was obtained from all the isolates (the data from 6 isolates are shown in fig. 1a, lanes 5-10). When PCR-amplified fragments were subjected to $N c i$ I restriction digestion, the original fragment from 13 isolates was resistant to digestion (indicating substitution of arginine by leucine at codon 463) while two fragments of 187 and $173 \mathrm{bp}$ from 5 other isolates (indicating the presence of arginine at codon 463) were obtained. The digestion patterns of DNA fragments from the 6 isolates shown in figure 1a, lanes 5-10 are shown in figure $1 \mathrm{~b}$, lanes $5-10$. The presence of leucine at codon 463 in the amplified fragment shown in figure 1a, lane 5 was confirmed by direct DNA sequencing of the amplified product (data not shown).

When PCR was performed with 17, 59 and 12 isoniazid-resistant isolates from Lebanon, Kuwait and UAE, respectively, specific amplification of a 360-bp DNA product was obtained, as expected. The restriction digestion of these PCR-amplified fragments with $\mathrm{Ncil}$ revealed that 3 of 17,46 of 55 , and 9 of 12 isoniazid-resistant isolates of $M$. tuberculosis from Lebanon, Kuwait and UAE, respectively, contained the substitution $\mathrm{R} 463 \mathrm{~L}$ at codon 463 (table 1). The data show that a great majority (46 of 55 or $78 \%$ ) of isoniazid-resistant clinical isolates of $M$. tuberculosis from Kuwait and 9 of 12 from the UAE contain R463L substitution at codon 463 . The prevalence of this mutation in isolates from Lebanon was quite low ( 3 of 17). Though none of the isoniazid-susceptible isolates from Lebanon contained leucine at codon 463 , the majority (13 of 18) isolates from Kuwait carried leucine instead of arginine at codon 463. All the isolates from Lebanon were recovered from patients of Middle Eastern origin (Lebanese nationals). The majority (33/59 and 8/12) of isoniazid-resistant strains from Kuwait and UAE were recovered from patients of South Asian origin. Correlating the R463L data with the ethnic group of the infected individuals from Kuwait and UAE showed that the prevalence of leucine at codon 463 was high in isolates recovered from patients of South Asian and Southeast Asian origin and low in patients of Middle Eastern origin (ta- 
Fig. 1. Amplification of the $k a t G$ gene region around codon 463 with primers KatG1F/KatG1R (a) and restriction digestion of the PCR-amplified products with $\operatorname{NciI}$ (b) from 4 isoniazid-susceptible clinical M. tuberculosis isolates from Lebanon (lanes 1-4) and 6 isolates from Kuwait (lanes 510). In $\mathbf{b}$, the pattern in lanes $1-4,8$ and 10 is characteristic of R463 while the pattern in lanes 5, 6, 8 and 9 is characteristic of substitution R463L at codon 463. Lane $\mathrm{M}$ is 100 bp DNA ladder and the position of migration of 100- and 600-bp fragments is marked.

Table 1. Occurrence of R463L mutation within the $k a t G$ gene in clinical M. tuberculosis isolates from the Middle East
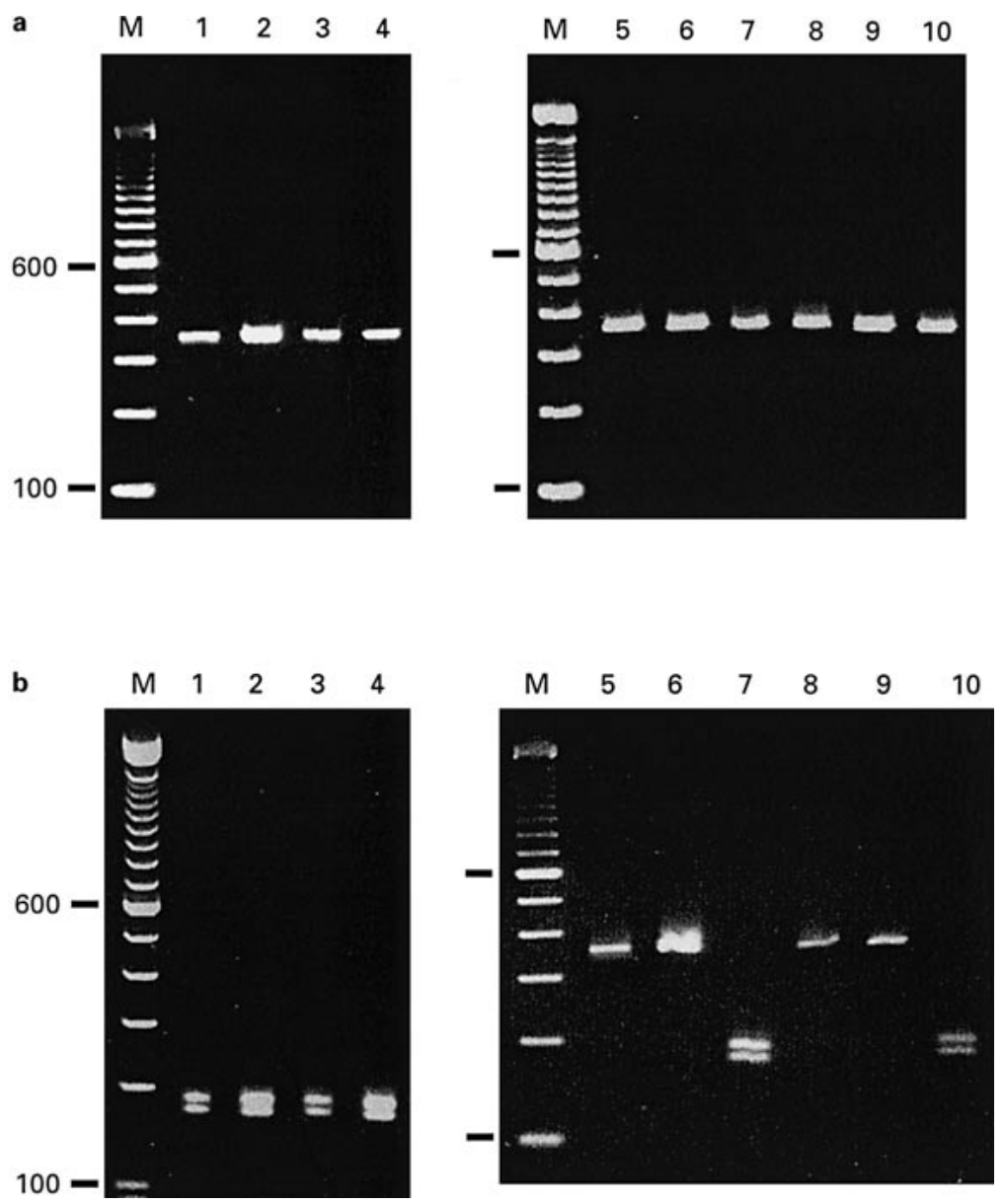

\begin{tabular}{|c|c|c|c|c|c|c|c|c|}
\hline \multirow[t]{2}{*}{ Country } & \multirow{2}{*}{$\begin{array}{l}\text { INH resistance } \\
\text { pattern }\end{array}$} & \multirow{2}{*}{$\begin{array}{l}\text { Total } \\
\text { isolates }\end{array}$} & \multicolumn{2}{|c|}{$\mathrm{R} 463 \mathrm{~L}$} & \multirow{2}{*}{$\begin{array}{l}\text { Ethnic } \\
\text { origin }\end{array}$} & \multirow{2}{*}{$\begin{array}{l}\text { Total } \\
\text { isolates }\end{array}$} & \multicolumn{2}{|c|}{ R463L } \\
\hline & & & $\mathrm{n}$ & $\%$ & & & $\mathrm{n}$ & $\%$ \\
\hline \multirow[t]{2}{*}{ Lebanon } & sensitive & 7 & 0 & 0 & ME & 7 & 0 & 0 \\
\hline & resistant & 17 & 3 & 18 & ME & 17 & 3 & 18 \\
\hline \multirow[t]{2}{*}{ UAE } & resistant & 12 & 9 & 75 & ME & 4 & 2 & 50 \\
\hline & & & & & SA & 8 & 7 & 87 \\
\hline \multirow[t]{5}{*}{ Kuwait } & sensitive & 18 & 13 & 72 & ME & 7 & 3 & 43 \\
\hline & & & & & SA & 11 & 10 & 91 \\
\hline & resistant & 59 & 46 & 78 & ME & 18 & 12 & 67 \\
\hline & & & & & SA & 33 & 27 & 81 \\
\hline & & & & & SEA & 8 & 7 & 87 \\
\hline
\end{tabular}

$\mathrm{INH}=$ Isoniazid ME = Middle Eastern; SA = South Asian; SEA = Southeast Asian. 
ble 1). The majority (11 of 18) of isoniazid-susceptible isolates from Kuwait were recovered from patients of South Asian origin and 10 of these isolates exhibited the presence of leucine at codon 463. However, none of the isoniazid-susceptible clinical isolates of $M$. tuberculosis recovered from Lebanese patients (Middle Eastern origin) contained leucine at codon 463 within the $k a t G$ gene. The prevalence of leucine at codon 463 within the $k a t G$ gene was also low (3 of 17) in isoniazid-resistant clinical isolates of $M$. tuberculosis recovered from Lebanese patients.

\section{Discussion}

Several kinds of mutations (missense/nonsense mutations and/or small deletions/insertions) in the $k a t G$ gene, encoding catalase-peroxidase, have been shown to confer resistance to isoniazid in isoniazid-resistant clinical isolates of M. tuberculosis [6]. Though R463 is almost exclusively present in the $k a t G$ gene in isoniazid-susceptible clinical isolates of M. tuberculosis from Europe and North America, the substitution R463L has been found in some clinical isolates that are weakly resistant to isoniazid $(\mathrm{MIC}<1 \mu \mathrm{g} / \mathrm{ml})[9,12,15]$. However, the significance of substitution $\mathrm{R} 463 \mathrm{~L}$ in conferring resistance to isoniazid is not clear. Studies carried out in Singapore showed that R463L substitution was present in 28 of $50(56 \%)$ isoniazid-sensitive isolates, indicating that geographical differences exist in the occurrence of R463 or L463 in the kat G gene [14]. This study involving 25 isoniazid-susceptible and 88 -resistant strains was carried out to determine the frequency of occurrence of arginine or leucine at codon 463 in $k a t G$ gene of clinical M. tuberculosis isolates recovered from TB patients in three Middle Eastern countries (Kuwait, Lebanon and UAE).

All the isoniazid-susceptible isolates of $M$. tuberculosis from Lebanon contained arginine at codon 463 (R463) in the $k a t G$ gene and only 3 of 17 (18\%) isoniazid-resistant isolates contained the substitution R463L. Since all the Lebanese isolates were recovered from Lebanese nationals, the data suggest that the clinical isolates recovered from Middle Eastern patients resemble those from $\mathrm{Eu}-$ rope and North America with respect to codon 463 in the $k a t G$ gene [8-10]. The majority of isoniazid-susceptible and -resistant clinical isolates of $M$. tuberculosis from Kuwait and UAE contained leucine at codon 463 (L463) within the $k a t G$ gene. The ethnic origin of the TB patients in Kuwait and UAE was mixed with the majority of patients coming from South Asian countries. The preva- lence of L463 was highest in isolates recovered from patients of South Asian origin (and Southeast Asian origin) and lowest in patients of Middle Eastern origin. This suggests that leucine is predominantly present at codon 463 in the $k a t G$ gene in $M$. tuberculosis isolates recovered from TB patients of South Asian and Southeast Asian origin. Though the prevalence of L463 in the kat G gene in clinical M. tuberculosis isolates from South Asian patients was not known, the data from patients originating from Southeast Asian countries are in agreement with earlier observations [15]. The slightly higher prevalence of L463 within the kat $G$ gene of $M$. tuberculosis in isolates recovered from TB patients of Middle Eastern origin in Kuwait and UAE may reflect transmission patterns of the infection since both these countries have large expatriate populations originating from South and Southeast Asian countries. It is probable that the majority of Middle Eastern patients (especially local Kuwaiti and UAE nationals) in these countries are acquiring the infection from patients of South Asian/Southeast Asian countries.

Our data show that the majority of clinical M. tuberculosis isolates recovered from South Asian patients, irrespective of susceptibility to isoniazid, contain leucine at codon 463 within the $k a t G$ gene. This together with other reports clearly shows that polymorphism exists at codon 463 in the $k a t G$ gene of $M$. tuberculosis [7-10, 12, 15]. The majority of isolates belonging to other members of the $M$. tuberculosis complex (M. bovis, M. microti and M. africanum) also contain leucine at codon 463 in the $k a t G$ gene and are fully susceptible to isoniazid [22]. This suggests that the presence of $\mathrm{R} 463$ or L463 within the kat G gene does not affect the susceptibility of $M$. tuberculosis to isoniazid.

\section{Acknowledgments}

This work was supported by Kuwait University Research Administration grant MI 116. We thank P.K. Akbar for technical assistance. 


\section{References}

1 Dye C, Scheele S, Dolin P, Pathania V, Raviglione MC: Consensus statement. Global burden of tuberculosis: Estimated incidence, prevalence, and mortality by country. WHO Global Surveillance and Monitoring Project. JAMA 1999;282:677-686.

2 Shafer RW, Small PM, Larkin C, Singh SP, Kelly P, Sierra MF, Schoolnik G, Chirgwin $\mathrm{KD}$ : Temporal trends and transmission patterns during the emergence of multidrug-resistant tuberculosis in New York city: A molecular epidemiological assessment. J Infect Dis 1995; 171:170-176.

3 Cohn DL, Bustreo F, Raviglione MC: Drugresistant tuberculosis: Review of the worldwide situation and the WHO/IUATLD global surveillance project. Clin Infect Dis 1997;24: S121-S130.

4 Siddiqi SH, Hawkins JE, Laszlo A: Interlaboratory drug susceptibility testing of Mycobacterium tuberculosis by radiometric procedure and two conventional methods. J Clin Microbiol 1985;22:919-923.

5 Hyem B, Honoroe N, Truffot-Pernot C, Banerjee A, Schurra C, Jacobs WR Jr, van Embden JDA, Grosset JH, Cole ST: The implications of multi-drug resistance for the future of shortcourse chemotherapy of tuberculosis: A molecular study. Lancet 1994;344:293-298.

6 Ramaswamy S, Musser JM: Molecular genetic basis of antimicrobial agent resistance in $\mathrm{Myco}$ bacterium tuberculosis: 1998 update. Tuber Lung Dis 1998:79:3-29.

7 Rouse DH, Li Z, Bai G-H, Morris SL: Characterization of the $k a t G$ and inhA genes of isoniazid-resistant clinical isolates of Mycobacterium tuberculosis. Antimicrob Agents Chemother 1995;39:2472-2477.

8 Cockerill FR III, Uhl JR, Temesgen Z, Zhang Y, Stockman L, Roberts GD, Williams DL, Kline BC: Rapid identification of a point mutation of the Mycobacterium tuberculosis catalase-peroxidase (katG) gene associated with isoniazid resistance. J Infect Dis 1995;171: 240-245.
9 Heym B, Alzari PM, Honore N, Cole ST: Missense mutations in the catalase-peroxidase gene, $k a t G$, are associated with isoniazid resistance in Mycobacterium tuberculosis. Mol Microbiol 1995; 15:235-245.

10 Musser JM, Kapur V, Williams DL, Kreiswirth BN, Van Soolingen D, Van Embden JDA: Characterization of the catalase-peroxidase gene (katG) and inhA locus in isoniazid-resistant and susceptible strains of Mycobacterium tuberculosis by automated DNA sequencing: Restricted array of mutations associated with drug resistance. J Infect Dis 1996;173:196202.

11 Heym B, Zhang Y, Poulet S, Young D, Cole ST: Characterization of the $k a t G$ gene encoding a catalase-peroxidase required for the isoniazid susceptibility of Mycobacterium tuberculosis. $\mathbf{J}$ Bacteriol 1993;175:4255-4259.

12 Marttila HJ, Soini H, Eerola E, Vyshnevskaya E, Vyshnevskaya BI, Otten TF, Vasilyef AV, Viljanen MK: A Ser315Thr substitution in $K a t G$ is predominant in genetically heterogenous multidrug-resistant Mycobacterium tuberculosis isolates originating from the St. Petersburg area. Antimicrob Agents Chemother 1998;42:2443-2445.

13 Van Soolingen D, de Haas PEW, van Doorn HR, Kuijper E, Rinder H, Borgdorff MW: Mutations at amino acid position 315 of the $k a t G$ gene are associated with high-level resistance to isoniazid, other drug resistance, and successful transmission of Mycobacterium tuberculosis in the Netherlands. J Infect Dis 2000;182:17881790.

14 Rouse DA, DeVito JA, Li Z, Byer H, Morris SL: Site-directed mutagenesis of the $k a t G$ gene of Mycobacterium tuberculosis: Effects on catalase/peroxidase activities and isoniazid resistance. Mol Microbiol 1996;22:583-592.
15 Lee AS-G, Tang LL-H, Lim IH-K, Ling M-L, Tay L, Wong S-Y: Lack of clinical significance for the common arginine-to-leucine substitution at codon 463 of the $k a t G$ gene in isoniazidresistant Mycobacterium tuberculosis in Singapore. J Infect Dis 1997;176:1125-1126.

16 Hamze MM, Araj GF: Drug resistance in $M y$ cobacterium tuberculosis isolates in Lebanon. Int J Tuberc Lung Dis 1997;1:314-318.

17 Mustafa AS, Chugh TD, Abal AT: Polymerase chain reaction targeting of single- and multiplecopy genes of mycobacteria in the diagnosis of tuberculosis. Nutrition Suppl 1995;11:665669.

18 Mustafa AS, Ahmed A, Abal AT, Chugh TD: Establishment and evaluation of a multiple polymerase chain reaction for detection of mycobacteria and specific identification of $\mathrm{Myco}^{-}$ bacterium tuberculosis complex. Tuber Lung Dis 1995;76:336-343.

19 Ahmad S, Araj GF, Akbar PK, Fares E, Chugh TD, Mustafa AS: Characterization of rpoB mutations in rifampin-resistant Mycobacterium tuberculosis isolates from the Middle East. Diagn Microbiol Infect Dis 2000;38:227-232.

20 Ahmad S, Akbar PK, Wiker HG, Harboe M, Mustafa AS: Cloning, expression and immunological reactivity of two mammalian cell entry proteins encoded by mcel operon of Mycobac terium tuberculosis. Scand J Immunol 1999;50 510-518.

21 Sambrook J, Fritsch EF, Maniatis T: Molecula Cloning: A Laboratory Manual, ed 2. Cold Spring Harbor, Cold Spring Harbor Laboratory Press, 1989.

22 Haas WH, Schilke K, Brand J, Amthor B, Weyer K, Fourie PB, Bretzel G, Sticht-Groh V, Bremer HJ: Molecular analysis of $k a t G$ gene mutations in strains of Mycobacterium $t u$ berculosis complex from Africa. Antimicrob Agents Chemother 1997;41:1601-1603. 